\title{
PENGEMBANGAN PEMBUATAN PLAFON DARI ABU SEKAM PADI DENGAN MENGGUNAKAN SERAT SABUT KELAPA
}

\author{
DEVELOPMENT OF MANUFACTURE OF CEILING USING RICE HUSK ASH AND \\ COCONUT COIR FIBER
}

\author{
Petrus Patandung \\ Balai Riset dan Standardisasi Industri Manado \\ Jalan Diponegoro No 21-23 \\ e-mail : patandungp@yahoo.com \\ Diterima tgl 19-05-2016, Disetujui tgl 26-05-2016
}

\begin{abstract}
ABSTRAK
Pengembangan pembuatan plafon dengan menggunakan abu sekam padi dan serat sabut kelapa sebagai bahan bangunan telah dilaksanakan. Tujuan penelitian ini adalah memanfaatkan abu sekam padi dan serat sabut kelapa yang belum digunakan secara maksimal, dan belum diolah atau diproses menjadi produk industri seperti untuk pembuatan plafon dengan bahan tambahan gypsum, semen dan dipress dengan menggunakan tekanan $500 \mathrm{~kg} / \mathrm{cm}^{2}$, dengan berbagai perlakuan: A; B; C; D dan $\mathrm{E}$ dan tiap perlakuan menggunakan $1600 \mathrm{~g}$ gypsum, semen $1000 \mathrm{~g}$, abu sekam padi $1000 \mathrm{~g}$ dan serat sabut kelapa: 135; 155; 175; 195 dan $215 \mathrm{~g}$. Penelitian ini menggunakan metode bentuk Tabelaris dan grafik serta data dianalisis secara deskriptif. Penelitian diulang 3 (tiga) kali. Hasil penelitian menunjukkan bahwa hasil bobot isi yaitu 1,48-1,82 $\mathrm{gr} / \mathrm{cm}^{3}$, penyerapan air 16,15-26,28\%, dan kuat lentur $61,06-105,80 \mathrm{~kg} / \mathrm{cm}^{2}$, kemampuan digergaji dan dipaku dalam keadaan baik, bidang potong yaitu campuran yang merata tidak berlubang dan tidak terbelah-belah, tepi potong yaitu lurus, rata, tidak mengerut, sama tebalnya, permukaan lembaran tidak retak-retak tidak berlubang atau cacat lain, kecuali perlakuan E permukaan lembaran tidak retak-retak tetapi agak berlubang atau cacat lain , tebal 4,8-4,93 $\mathrm{mm}$, penyimpangan: panjang $0,00-0,48 \%$, lebar $0,00-0,46 \%$ serta tebal $0,00-8,12 \%$. Hasil penelitian menunjukkan bahwa perlakuan yang terbaik diperoleh pada parlakuan $B, C$ dan $D$ dengan menghasilkan kuat lentur 100,15-105,80 kg/cm² dapat dipaku, digergaji dan tidak terjadi tetesan air.
\end{abstract}

Kata Kunci: Abu sekam padi, serat sabut kelapa, plafon, kuat lentur

\section{ABSTRACT}

Development of ceiling manufacture using rice husk ash and coconut coir fiber as a building material has been implemented. The purpose of this study is utilizing rice husk ash and coconut coir fiber that has not been used optimally into industrial products to manufacture ceiling with additional material gypsum, cement and pressed using a pressure of $500 \mathrm{~kg} / \mathrm{cm}^{2}$, with different treatments: $A ; B ; C ; D$ and $E$, and each treatment using $1600 \mathrm{~g}$ gypsum, cement $1000 \mathrm{~g}, 1000 \mathrm{~g}$ of rice husk ash and coconut coir fiber: 135; 155; 175; 195 and $215 \mathrm{~g}$. This study uses Tabelaris and graph form and the data were analyzed descriptively. The study was repeated three times. The results showed that the results of bulk density is 1.48 to $1.82 \mathrm{~g} / \mathrm{cm}^{3}$, water absorption of 16.15 to $26.28 \%$, and flexural strength of $61,06-105,80 \mathrm{~kg} / \mathrm{cm}^{2}$, the ability to be sawed and nailed for still in good condition, pieces that mix evenly, not perforated and does not split apart, straight cutting edge, flat, not contracting, smooth thickness, the sheet surface does not crack and no holes or other defects visible. Except treatment E, sheet surface is not cracked but with few cavities or other defects, thickness from 4.8 to $4.93 \mathrm{~mm}$, a deviation length of 0.00 to $0.48 \%$, a deviation width of 0.00 to $0.46 \%$ and the deviation thickness of 0.00 to $8.12 \%$. The results showed that the best treatment was obtained at treatment of $B, C$ and $D$ to produce a piece with flexural strength of 100.15 to $105.80 \mathrm{~kg} / \mathrm{cm}^{2}$ that can be nailed, sawed and no occurring water droplets.

Keywords: rice husk ash, coconut coir fiber, ceilings, flexural strength

\section{PENDAHULUAN}

Pembangunan di Indonesia

dewasa ini setiap tahun meningkat dengan pesat, menyebabkan kebutuhan papan dan permintaan perumahan rakyat cukup tinggi yang memerlukan atau membutuhkan bahan-bahan plafon. Produk bahan bangunan yang berbentuk plafon adalah sebagai bahan bangunan yang merupakan bidang pembatas antara atap rumah dan 
ruangan dibawahnya dengan ketinggian palfon atau langit-langit rumah umumnya berkisar 2,75 s/d 3,75 m. Plafon rumah mempunyai banyak fungsi yaitu untuk menjaga kondisi suhu didalam ruangan akibat sinar matahari yang menyinari atap rumah, uap panas di ruang atap mengalir keruang dibawahnya sehingga suhu ruang dibawahnya tetap terjaga. Disamping itu plafon berfungsi untuk melindungi ruanganruangan didalam rumah dari rembesan air dari atas atap, serta menetralkan bunyi atau suara nyaring dan bising pada atap disaat hujan, selain itu juga plafon dapat membantu menutup dan menyembunyikan benda-benda seperti kabel instalasi listrik, struktur atap sehingga interior ruangan tampak lebih indah serta dirancang sedemikian rupa untuk memberi kesan estetika khususnya pada interior ruangan [1]. Kualitas dan mutu plafon ditentukan oleh material yang digunakan sebagai bahan baku dan bahan pengisi serta bahan tambahan yang digunakan seperti abu sekam padi dan bahan-bahan selulosa seperti serat sabut kelapa, gipsum dan semen. Data dari Dinas Pertanian dan Ketahanan Pangan, Provinsi Sulawesi Utara luas areal persawahan tahun 2011 adalah sebesar $109.740 \mathrm{Ha}$ dengan produksi 193.308 ton/tahun .

Abu sekam padi yang cukup potensial untuk diolah menjadi produk industri, yang sampai sekarang belum dimanfaatkan secara maksimal dibidang industri dan merupakan salah satu sumber silika yang cukup tinggi selain dari sumber silika lainnya yaitu semen, tetapi silika dari sekam padi mempunyai keuntungan karena jumlah elemen lain (pengotor) yang tidak diinginkan adalah sangat kecil atau sedikit dibanding dengan jumlah silikanya yaitu abu yang diperoleh dari pembakaran sekam padi. Daerah Sulawesi Utara merupakan suatu daerah yang cukup potensial untuk tanaman kelapa, menurut data dari Dinas Perkebunan Provinsi Sulawesi Utara tahun 2015 adalah seluas $280.107 \mathrm{Ha}$ dengan produksi 254.641 ton/tahun. Salah satu bagian dari buah kelapa yaitu sabut yang terdiri dari serat sabut kelapa dan serbuk sabut kelapa" coco dust " [2]. Serat sabut kelapa sampai sekarang belum dimanfaatkan secara maksimal untuk kebutuhan industri dan hanya dieksport keluar negeri seperti Amerika, Australia dan Negara-negara lainnya. Dari bahan- bahan tersebut dapat diolah menjadi barang industri dan bahan pengisi atau bahan tambahan untuk produk-produk yaitu untuk pembuatan plafon yang dapat membentuk produk yang bersifat komposit, sehingga dalam proses pembuatannya memerluhkan tekanan agar lebih menyatuh dan dapat menghasilkan produk yang lebih padat. Balai Riset dan Standardisasi Industri Manado lewat kegiatan Tahun 2013 yaitu Pemanfaatan Abu Sekam Padi dan Serat Sabut Kelapa untuk Pembuatan Eternit/Plafon, tetapi hasilnya belum maksimal karena ada parameter yang belum memenuhi Standar lembaran serat semen yaitu kemampuan dipaku belum sempurna. Berdasarkan hal tersebut, maka Balai Riset dan Standardisasi Industri Manado akan memprogramkan lewat kegiatan tahun 2015 yaitu Pengembangan Pembuatan plafon dengan menggunakan Abu Sekam Padi dan Serat Sabut kelapa untuk Bahan 
Bangunan.Abu Sekam padi pada umumnya digunakan sebagai bahan bakar atau bahan tambahan dalam industri, bahkan dibuang begitu saja.Abu sekam padi diperoleh dari pembakaran sekam padi dengan menggunakan suhu $500-700{ }^{\circ} \mathrm{C}$ yang mengandung banyak silika amorf. Komposisi abu sekam padi adalah sebagai berikut: $\mathrm{SiO}_{2}=86,96-97,30 \%, \mathbf{K}_{2} \mathrm{O}=0,58$ $2,50 \%, \mathrm{Na}_{2} \mathrm{O}=0,00-1,75 \%, \mathrm{CaO}=0,20-$ $1,50 \%, \mathrm{MgO}=0,12-1,96 \%, \mathrm{Fe}_{2} \mathrm{O} 3=0,00-$ $0,54 \%, \mathrm{P}_{2} \mathrm{O}_{5}=0,20-2,84 \%, \mathrm{SO}_{3}=0,10-$ $1,13 \%$ dan $\mathrm{Cl}=0,00-0,42 \%$. Berdasarkan komposisinya, buah kelapa terdiri dari sabut kelapa $35 \%$, daging buah $28 \%$ dan air kelapa $25 \%$ tempurung $12 \%$.

Serat sabut kelapa, Jika direntangkan akan ketambahan panjang sesuai dengan aslinya, dan mempunyai panjang $15-30 \mathrm{~cm}$ serta memiliki sifat-sifat spesifik seperti tahan terhadap air, serangan organisme, pelapukan dan terhadap pengerjaan mekanis dan gesekan serta lebih ringan bila di bandingkan dengan serat-serat alami lainnya. Dengan demikian sifat-sifat spesifik tersebut sehingga serat sabut kelapa dapat dimanfaatkan untuk produkproduk yang lebih halus seperti tikar, karung goni, karpet dan bahan pengisi atau tambahan untuk produk bahan bangunan. Serat sabut kelapa sebagai penguat bahan, memperkuat komposit sehingga sifat mekaniknya lebih kaku, tangguh dan lebih kokoh dibandingkan dengan tanpa serat penguat, selain itu juga serat dapat menghemat penggunaan resin .

Eternit/ plafon merupakan bahasa serapan dari bahasa Belanda "plafon "yang sama artinya dengan kata "ceiling "dalam bahasa Inggris dan langit-langit dalam bahasa Indonesia. Eternit/plafon adalah interior permukaan bagian atas dari ruangan yang digunakan untuk menutupi sebagian atas atau seluruh struktur dasar atap.

Dalam perdagangan, plafon juga dikenal dengan nama eternit, menurut Ensiklopedia Indonesia, eternit adalah nama perdagangan dari barang-barang semen asbes dan serta dibubuhi bahan-bahan lain lalu ditekan dengan tekanan tinggi. Biasanya dalam bentuk lembaran dan dipakai untuk langit-langit rumah atau komponen bangunan lainnya

Teknologi pembuatan eternit atau plafon biasanya dibuat dari campuran semen dan gypsum serta serat-serat seperti rami, serat-serat pakaian bekas atau kertas sebagai pengganti asbes, bahan-bahan tersebut dicampur dalam perbandingan 25 bagian semen, 10 bagian gipsum atau mill dan 1 bagian serat. Lembaran-lembaran etrnit/plafon umumnya berukuran panjang $100 \mathrm{~cm}$, lebar $100 \mathrm{~cm}$ dan tebal $0,5 \mathrm{~cm}$. Dengan demikian produk ini dapat digolongkan sebagai lembaran serat semen(SNI 15-0233-1989). Lembaran serat semen (non asbes) adalah suatu campuran serat tumbuhan-tumbuhan dan semen Portland atau semen sejenis ditambah air, tanpa atau dengan bahan tambahan lainnya, dengan bobot isi lebih dari 1,2 $\mathrm{g} / \mathrm{cm}^{3}$ dan dipergunakan untuk bangunan [3[.

Syarat mutu lembaran serat semen yaitu bentuk/pandangan luar: lembaran serat semen harus punya tepi potongan yang lurus, rata dan tidak mengkerut, sama tebalnya, bersuara nyaring jika disentuh dengan benda keras yang menunjukkan 
bahwa lembaran tidak pecah atau retak, permukaan lembaran harus tidak menunjukkan retak-retak,kerutankerutanatau cacat lain yang dapat mempengaruhi sifat pemakaiannya, bidang potong lembaran harus menunjukkan campuran yang merata, tidak berlubanglubang atau tidak terbelah-belah, lembaran harus mudah dipotong; digergaji, digerek dan dipaku tanpa menunjukkan terjadinya cacat atau retakan. Sedangkan ukuran dan sifat-sifat: tebal minimum $4 \mathrm{~mm}$, dengan penyimpangan maksimum $10 \%$, penyimpangan ukuran panjang dan lebar maksimum $1 \%$, penyerapan air maksimum $35 \%$, kerapatan air harus baik (tidak terjadi tetesan) dan kuat lentur minimum 100 $\mathrm{kg} / \mathrm{cm}^{2}$.

Plafon merupakan bidang pembatas antara atap rumah dan ruangan dibawahnya dan ketinggian plafon atau langit-langit rumah umumnya berkisar antara 2,75 s/d 3,75 m. Plafon rumah memiliki banyak fungsi yaitu untuk menjaga kondisi suhu didalam ruangan akibat sinar matahari yang menyinari atap rumah yang mengakibatkan udara panas diruangan ditahan oleh plafon sehingga tidak langsung mengalir keruang dibawahnya sehingga suhu ruangan tetap serta juga berfungsi untuk melindungi ruanganruangan didalam rumah dari perembesan air yang masuk dari atas atap rumah, menetralkan suara yang bising dari atap pada saat hujan dan juga plafon dapat membantu menutup dan menyembunyikan benda-benda seprti kabel instalasi listrik, pipa telepon dan struktur atap sehingga interior ruangan tampak lebih indah. Kualitas plafon rumah dipengaruhi oleh bahan atau material plafon yang dipakai, dimana setiap bahan atau material plafon mempunyai karakteristik yang berbedabeda [4].

Gipsum adalah merupakan mineral terbanyak dalam batuan sedimen dan lunak bila murni, dan merupakan bahan baku yang dapat diolah menjadi kapur tulis, yang dalam perdagangan biasanya gipsum mengandung $90 \% \mathrm{CaSO}_{4} \cdot \mathrm{H}_{2} \mathrm{O}$. Kata gipsum berasal bahasa Yunani yang berarti memasak serta begitu tidak larut dalam air. Gipsum dapat digolongkan menjadi 2 (dua) macam yaitu: yang belum mengalami kalsinasi dapat digunakan dalam pembuatan semen Porland dan sebagai pupuk serta yang mengalami proses kalsinasi yang sebagian besar digunakan sebagai bahan bangunan, bahan dasar untuk pembuatan kapur, bedak, cetakan keramik, tuangan logam, dan gigi. Gipsum digunakan sebagai bahan perekat, mineral mempunyai sifat yang lebih baik dibandingkan dengan perekat organik karena tidak menimbulkan pencemaran udara, murah tahan api, tahan deteriorasi oleh faktor biologi dan tahan terhadap zat kimia dan juga gipsum mempunyai sifat yang cepat mengeras yaitu sekitar 5-10 menit. Saat ini gipsum sebagai bahan bangunan yang berfungsi untuk mengeraskan bahan campuran untuk papan gipsum dan profil pengganti tripleks dari kayu. Papan gipsum dan profil adalah salah satu produk jadi setelah material gipsum diolah melalui pabrikasi menjadi tepung sehingga dapat digunakan untuk pembuatan profil dan juga digunakan sebagai plafon, papan partisi dan memiliki kemampuan untuk dihias serta menjadi 
lebih kuat apabila mengalami penekanan [5].Tujuan Penelitian ini memanfaatkan abu sekam padi dan serat sabut kelapa yang belum digunakan secara maksimal, dan belum diolah atau diproses menjadi plafon sebagai bahan bangunan.

\section{BAHAN DAN METODE}

\section{Bahan dan Alat}

Bahan yang digunakan yaitu abu sekam padi, serat sabut kelapa, gypsum,semen, Sedangkan alat yang digunakan yaitu: alat cetak plafon 1 (satu) unit, kuat lentur 1 (satu) unit, sendok semen, ayakan 10 mesh, penampan, loyang plastik dan rak pengering.

\section{Metode Penelitian}

Dilakukan penelitian pendahuluan dengan variasi jumlah gypsum dan serat sabut kelapa, abu sekam padi dan semen konstan yang terdiri dari: $A=1500 \mathrm{~g}$ gypsum, semen $1000 \mathrm{~g}$ dan abu sekam padi $1000 \mathrm{~g}$ dan serat sabut kelapa $150 \mathrm{~g}$, $\mathrm{B}=1600 \mathrm{~g}$ gypsum, semen $1000 \mathrm{~g}$, abu sekam padi $1000 \mathrm{~g}$ dan serat sabut kelapa $175 \mathrm{~g}, \mathrm{C}=1700 \mathrm{~g}$ gypsum, semen 1000 g,abu sekam padi $1000 \mathrm{~g}$ dan serat sabut kelapa $200 \mathrm{~g}, \mathrm{D}=1800 \mathrm{~g}$ gypsum, semen $1000 \mathrm{~g}$, abu sekam padi $1000 \mathrm{~g}$ dan serat sabut kelapa $225 \mathrm{~g}$ dengan menggunakan tekanan $500 \mathrm{~kg} / \mathrm{cm}^{2}$. Dari hasil penelitian yang terbaik diperoleh pada perlakuan $\mathrm{B}=1600 \mathrm{~g}$ gypsum, semen $1000 \mathrm{~g}$, abu sekam padi $1000 \mathrm{~g}$ dan serat sabut kelapa $175 \mathrm{~g}$, serta menjadi penelitian lanjutan. Hasil analisis dapat dilihat pada Tabel 1 dan 2.Data disusun dalam bentuk Tabelaris dan grafik serta data dianalisis secara deskriptif. Penelitian diulang 3 (tiga) kali.

\section{Tahapan Penelitian}

a. Persiapan Bahan.

Abu sekam padi dibersihkan dari kotoran, kemudian diayak sesuai dengan dengan ukuran lewat lolos ayakan yaitu 10 mesh dan serat sabut kelapa dipotong-potong dengan ukuran $1-5 \mathrm{~cm}$.

b. Penelitian Lanjutan

Penelitian dilanjutkan dengan perlakuan yang terdiri dari: $A=1600$ gypsum, semen $1000 \mathrm{~g}$, abu sekam padi $1000 \mathrm{~g}$ dan serat sabut kelapa $135 \mathrm{~g}, \mathrm{~B}=1600 \mathrm{~g}$ gypsum, semen $1000 \mathrm{~g}$,abu sekam padi $1000 \mathrm{~g}$ dan serat sabut kelapa $155 \mathrm{~g}$, $\mathrm{C}=1600 \mathrm{~g}$ gypsum, semen $1000 \mathrm{~g}$, abu sekam padi $1000 \mathrm{~g}$ dan serat sabut 175 g, $D=1600 \mathrm{~g}$ gypsum, semen $1000 \mathrm{~g}$, abu sekam padi $1000 \mathrm{~g}$ dan serat sabut kelapa $195 \mathrm{~g}$ dan $\mathrm{E}=1600 \mathrm{~g}$ gypsum, semen $1000 \mathrm{~g}$, abu sekam padi $1000 \mathrm{~g}$ dan serat sabut kelapa $215 \mathrm{~g}$.

\section{Pembuatan Adonan}

Mula-mula abu sekam padi ditimbang sesuai dengan perlakuan kemudian ditambahakan serat sabut kelapa, abu sekam padi, gypsum, semen, dicampur sampai merata, lalu ditambahakan air secukupnya diaduk dengan menggunakan sendok semen sampaimerata, sehingga membentuk campuran yang menyerupai lumpur. Adonan yang siap dicetak diangkat dan dihamparkan diatas cetakan yang sebelumnya diolesi minyak solar atau oli bekas yang berfungsi untuk mencegah melekatnya adonan pada cetakan. Masa atau adonan tersebut kemudian diratakan dengan seterika atau sendok semen diseluruh permukaan cetakan berukuran 50 $\times 50 \times 0,5 \mathrm{~cm}$. selanjutnya ditaburi buburan 
yaitu campuran gipsum dan semen $2: 1$ dan dicetak dengan menggunakan tekanan.

\section{Perawatan}

Produk plafon yang telah dicetak diletakkan pada lembaran penampan dan ditempatkan dalam ruangan tertutup selama 1(satu) minggu, produk dilepaskan dari penampan dan kemudian dikeringkan selama 1 (satu) sampai dengan 4 (empat) minggu untuk dianalisis.

\section{Parameter yang Diukur}

Parameter yang diukur yaitu: bentuk/pandangan luar, tepi potong, kemampuan dipaku, kemampuan digergaji,
Sifat fisik: tebal, penyimpangan ukuran, bobot isi, penyerapan air, kerapatan air dan kuat lentur (SNI 15- 0233-1989).

\section{BAB IV}

\section{HASIL DAN PEMBAHASAN}

\section{Pengujian Laboratorium}

Produk plafon yang menggunakan abu sekam padi, serat sabut kelapa, gypsum dan semen dengan menggunakan tekanan $500 \mathrm{~kg} / \mathrm{cm}^{2}$ dapat dilihat pada Gambar 1, sedangkan hasil pengujian laboratorium dapat dilihat pada Tabel 1 dan 2 serta Gambar grafik 2; 3 dan 4.

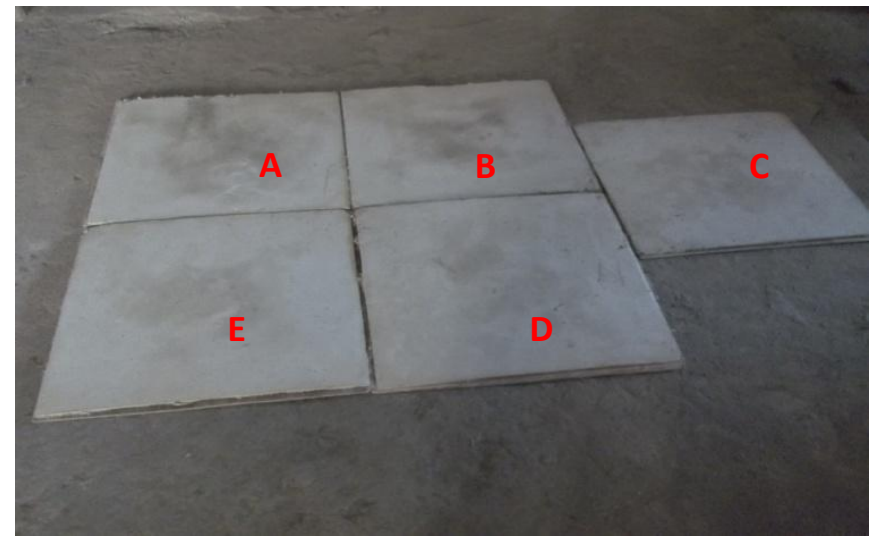

Gambar 1. Produk Plafon

\section{Keterangan:}

$\mathrm{A}=$ Produk plafon yang menggunakan serat sabut kelapa $135 \mathrm{~g}$.

$\mathrm{B}=$ Produk plafon yang menggunakan serat sabut kelapa $155 \mathrm{~g}$.

$\mathrm{C}=$ Produk plafon yang menggunakan serat sabut kelapa $175 \mathrm{~g}$

$\mathrm{D}=$ Produk plafon yang menggunakan serat sabut kelapa $195 \mathrm{~g}$.

$\mathrm{E}=$ Produk plafon yang menggunakan serat sabut kelapa $215 \mathrm{~g}$. 
Tabel 1. Hasil Analisis Bentuk/Pandangan Luar dari Produk Plafon

\begin{tabular}{|c|c|c|c|c|c|c|}
\hline \multirow{2}{*}{\multicolumn{2}{|c|}{ Perlakuan }} & \multirow{2}{*}{ Tepi Potong } & \multirow{2}{*}{ Permukaan Lembaran } & \multirow{2}{*}{ Bidang Potong } & \multicolumn{2}{|c|}{ Kemampuan } \\
\hline & & & & & Digergaji & Dipaku \\
\hline \multirow{3}{*}{ A } & $\mathrm{A} 1$ & $\begin{array}{l}\text { Lurus, rata, } \\
\text { tidak mengerut, } \\
\text { sama tebalnya }\end{array}$ & $\begin{array}{l}\text { Tidak retak-retak, tidak } \\
\text { berlubang atau cacat lain }\end{array}$ & $\begin{array}{l}\text { Campuran yang merata, } \\
\text { tidak berlubang, tidak } \\
\text { terbelah-belah }\end{array}$ & Baik & Baik \\
\hline & $\mathrm{A} 2$ & $\begin{array}{l}\text { Lurus, rata, } \\
\text { tidak mengerut, } \\
\text { sama tebalnya }\end{array}$ & $\begin{array}{l}\text { Tidak retak-retak, tidak } \\
\text { berlubang atau cacat lain }\end{array}$ & $\begin{array}{l}\text { Campuran yang merata, } \\
\text { tidak berlubang, tidak } \\
\text { terbelah-belah }\end{array}$ & Baik & Baik \\
\hline & A3 & $\begin{array}{l}\text { Lurus, rata, } \\
\text { tidak mengerut, } \\
\text { sama tebalnya }\end{array}$ & $\begin{array}{l}\text { Tidak retak-retak, tidak } \\
\text { berlubang atau cacat lain }\end{array}$ & $\begin{array}{l}\text { Campuran yang merata, } \\
\text { tidak berlubang, tidak } \\
\text { terbelah-belah }\end{array}$ & Baik & Baik \\
\hline \multirow{3}{*}{ B } & B1 & $\begin{array}{l}\text { Lurus, rata, } \\
\text { tidak mengerut, } \\
\text { sama tebalnya }\end{array}$ & $\begin{array}{l}\text { Tidak retak-retak, tidak } \\
\text { berlubang atau cacat lain }\end{array}$ & $\begin{array}{l}\text { Campuran yang merata, } \\
\text { tidak berlubang, tidak } \\
\text { terbelah-belah }\end{array}$ & Baik & Baik \\
\hline & B2 & $\begin{array}{l}\text { Lurus, rata, } \\
\text { tidak mengerut, } \\
\text { sama tebalnya }\end{array}$ & $\begin{array}{l}\text { Tidak retak-retak, tidak } \\
\text { berlubang, atau cacat } \\
\text { lain }\end{array}$ & $\begin{array}{l}\text { Campuran yang merata, } \\
\text { tidak berlubang, tidak } \\
\text { terbelah-belah }\end{array}$ & Baik & Baik \\
\hline & B3 & $\begin{array}{l}\text { Lurus, rata, } \\
\text { tidak mengerut, } \\
\text { sama tebalnya }\end{array}$ & $\begin{array}{l}\text { Tidak retak-retak, tidak } \\
\text { berlubang, atau cacat } \\
\text { lain }\end{array}$ & $\begin{array}{l}\text { Campuran yang merata, } \\
\text { tidak berlubang, tidak } \\
\text { terbelah-belah }\end{array}$ & Baik & Baik \\
\hline \multirow{3}{*}{ C } & $\mathrm{C} 1$ & $\begin{array}{l}\text { Lurus, rata, } \\
\text { tidak mengerut, } \\
\text { sama tebalnya }\end{array}$ & $\begin{array}{l}\text { Tidak retak-retak, tidak } \\
\text { berlubang, atau cacat } \\
\text { lain }\end{array}$ & $\begin{array}{l}\text { Campuran yang merata, } \\
\text { tidak berlubang, tidak } \\
\text { terbelah-belah }\end{array}$ & Baik & Baik \\
\hline & $\mathrm{C} 2$ & $\begin{array}{l}\text { Lurus, rata, } \\
\text { tidak mengerut, } \\
\text { sama tebalnya }\end{array}$ & $\begin{array}{l}\text { Tidak retak-retak, tidak } \\
\text { berlubang, atau cacat } \\
\text { lain }\end{array}$ & $\begin{array}{l}\text { Campuran yang merata, } \\
\text { tidak berlubang, tidak } \\
\text { terbelah-belah }\end{array}$ & Baik & Baik \\
\hline & C3 & $\begin{array}{l}\text { Lurus, rata, } \\
\text { tidak mengerut, } \\
\text { sama tebalnya }\end{array}$ & $\begin{array}{l}\text { Tidak retak-retak, tidak } \\
\text { berlubang, atau cacat } \\
\text { lain }\end{array}$ & $\begin{array}{l}\text { Campuran yang merata, } \\
\text { tidak berlubang, tidak } \\
\text { terbelah-belah }\end{array}$ & Baik & Baik \\
\hline \multirow{3}{*}{ D } & D1 & $\begin{array}{l}\text { Lurus, rata, } \\
\text { tidak mengerut, } \\
\text { sama tebalnya }\end{array}$ & $\begin{array}{l}\text { Tidak retak-retak, tidak } \\
\text { berlubang, atau cacat } \\
\text { lain }\end{array}$ & $\begin{array}{l}\text { Campuran yang merata, } \\
\text { tidak berlubang, tidak } \\
\text { terbelah-belah }\end{array}$ & Baik & Baik \\
\hline & D2 & $\begin{array}{l}\text { Lurus, rata, } \\
\text { tidak mengerut, } \\
\text { sama tebalnya }\end{array}$ & $\begin{array}{l}\text { Tidak retak-retak, tidak } \\
\text { berlubang, atau cacat } \\
\text { lain }\end{array}$ & $\begin{array}{l}\text { Campuran yang merata, } \\
\text { tidak berlubang, tidak } \\
\text { terbelah-belah }\end{array}$ & Baik & Baik \\
\hline & D3 & $\begin{array}{l}\text { Lurus, rata, } \\
\text { tidak mengerut, } \\
\text { sama tebalnya }\end{array}$ & $\begin{array}{l}\text { Tidak retak-retak, tidak } \\
\text { berlubang, atau cacat } \\
\text { lain }\end{array}$ & $\begin{array}{l}\text { Campuran yang merata, } \\
\text { tidak berlubang, tidak } \\
\text { terbelah-belah }\end{array}$ & Baik & Baik \\
\hline \multirow{3}{*}{$E$} & $\mathrm{E} 1$ & $\begin{array}{l}\text { Lurus, rata, } \\
\text { tidak mengerut, } \\
\text { sama tebalnya }\end{array}$ & $\begin{array}{l}\text { Tidak retak-retak, agak } \\
\text { berlubang, atau cacat } \\
\text { lain }\end{array}$ & $\begin{array}{l}\text { Campuran yang merata, } \\
\text { tidak berlubang, tidak } \\
\text { terbelah-belah }\end{array}$ & Baik & Baik \\
\hline & E2 & $\begin{array}{l}\text { Lurus, rata, } \\
\text { tidak mengerut, } \\
\text { sama tebalnya }\end{array}$ & $\begin{array}{l}\text { Tidak retak-retak, agak } \\
\text { berlubang, atau cacat } \\
\text { lain }\end{array}$ & $\begin{array}{l}\text { Campuran yang merata, } \\
\text { tidak berlubang, tidak } \\
\text { terbelah-belah }\end{array}$ & Baik & Baik \\
\hline & E3 & $\begin{array}{l}\text { Lurus, rata, } \\
\text { tidak mengerut, } \\
\text { sama tebalnya }\end{array}$ & $\begin{array}{l}\text { Tidak retak-retak, agak } \\
\text { berlubang, atau cacat } \\
\text { lain }\end{array}$ & $\begin{array}{l}\text { Campuran yang merata, } \\
\text { tidak berlubang, tidak } \\
\text { terbelah-belah }\end{array}$ & Baik & Baik \\
\hline
\end{tabular}

Keterangan:

$\mathrm{A} 1=\mathrm{A} 2=\mathrm{A} 3(\mathrm{~A})$ = Contoh yang menggunakan gypsum $1600 \mathrm{~g}$, semen $1000 \mathrm{~g}$, abu sekam padi $1000 \mathrm{~g}$ dan serat sabut kelapa $135 \mathrm{~g}$

$\mathrm{B} 1=\mathrm{B} 2=\mathrm{B} 3(\mathrm{~B})$ = Contoh yang menggunakan gypsum $1600 \mathrm{~g}$, semen $1000 \mathrm{~g}$, abu sekam padi $1000 \mathrm{~g}$ dan serat sabut kelapa $155 \mathrm{~g}$

$\mathrm{C} 1=\mathrm{C} 2=\mathrm{C} 3(\mathrm{C})$ = Contoh yang menggunakan gypsum $1600 \mathrm{~g}$, semen $1000 \mathrm{~g}$, abu sekam padi $1000 \mathrm{~g}$ dan serat sabut kelapa $175 \mathrm{~g}$

D1=D2=D3 (D) = Contoh yang menggunakan gypsum $1600 \mathrm{~g}$, semen $1000 \mathrm{~g}$,abu sekam padi $1000 \mathrm{~g}$ dan serat sabut kelapa $195 \mathrm{~g}$

$\mathrm{E} 1=\mathrm{E} 2=\mathrm{E} 3(\mathrm{E})$ = Contoh yang menggunakan gypsum $1600 \mathrm{~g}$, semen $1000 \mathrm{~g}$, abu sekam padi $1000 \mathrm{~g}$ dan serat sabut kelapa 215 . 
Tabel 2. Hasil analisis ukuran dan sifat-sifat fisik dari produk-produk plafon

\begin{tabular}{|c|c|c|c|c|c|c|c|c|c|c|}
\hline \multirow{2}{*}{\multicolumn{2}{|c|}{ Perlakuan }} & \multirow{3}{*}{\multicolumn{2}{|c|}{$\begin{array}{r}\text { Tebal }(\mathbf{m m}) \\
\begin{array}{c}\text { rata- } \\
\text { rata }\end{array} \\
\end{array}$}} & \multicolumn{6}{|c|}{ Penyimpangan (\%) } & \multirow{3}{*}{ Kerapatan Air } \\
\hline & & & & \multicolumn{2}{|c|}{ Panjang } & \multicolumn{2}{|c|}{ Lebar } & \multicolumn{2}{|c|}{ Tebal } & \\
\hline & & & & & $\begin{array}{l}\text { rata- } \\
\text { rata }\end{array}$ & & $\begin{array}{l}\text { rata- } \\
\text { rata }\end{array}$ & & $\begin{array}{l}\text { rata- } \\
\text { rata }\end{array}$ & \\
\hline \multirow{3}{*}{ A } & A1 & 4.90 & \multirow{3}{*}{4.92} & 0.48 & \multirow{3}{*}{0.48} & 0.45 & \multirow{3}{*}{0.46} & 8.00 & \multirow{3}{*}{8.12} & $\begin{array}{l}\text { tidak terjadi } \\
\text { tetesan }\end{array}$ \\
\hline & $\mathbf{A} 2$ & 4.95 & & 0.48 & & 0.46 & & 8.15 & & $\begin{array}{l}\text { tidak terjadi } \\
\text { tetesan }\end{array}$ \\
\hline & A3 & 4.90 & & 0.48 & & 0.48 & & 8.20 & & $\begin{array}{l}\text { tidak terjadi } \\
\text { tetesan }\end{array}$ \\
\hline \multirow{3}{*}{$\mathrm{B}$} & B1 & 4.85 & \multirow{3}{*}{4.88} & 0.00 & \multirow{3}{*}{0.00} & 0.00 & & 0.00 & \multirow{3}{*}{0.00} & $\begin{array}{l}\text { tidak terjadi } \\
\text { tetesan }\end{array}$ \\
\hline & B2 & 4.9 & & 0.00 & & 0.00 & 0.00 & 0.00 & & $\begin{array}{l}\text { tidak terjadi } \\
\text { tetesan }\end{array}$ \\
\hline & B3 & 4.9 & & 0.00 & & 0.00 & & 0.00 & & $\begin{array}{l}\text { tidak terjadi } \\
\text { tetesan }\end{array}$ \\
\hline \multirow{3}{*}{$\mathrm{C}$} & C1 & 4.9 & \multirow{3}{*}{4.92} & 0.00 & \multirow{3}{*}{0.00} & 0.00 & & 0.00 & \multirow{3}{*}{0.00} & $\begin{array}{l}\text { tidak terjadi } \\
\text { tetesan }\end{array}$ \\
\hline & $\mathrm{C} 2$ & 4.9 & & 0.00 & & 0.00 & 0.00 & 0.00 & & $\begin{array}{l}\text { tidak terjadi } \\
\text { tetesan }\end{array}$ \\
\hline & C3 & 4.95 & & 0.00 & & 0.00 & & 0.00 & & $\begin{array}{l}\text { tidak terjadi } \\
\text { tetesan }\end{array}$ \\
\hline \multirow{3}{*}{$\mathrm{D}$} & D1 & 5 & \multirow{3}{*}{4.93} & 0.00 & \multirow{3}{*}{0.00} & 0.00 & & 0.00 & \multirow{3}{*}{0.00} & $\begin{array}{l}\text { tidak terjadi } \\
\text { tetesan }\end{array}$ \\
\hline & D2 & 4.9 & & 0.00 & & 0.00 & 0.00 & 0.00 & & $\begin{array}{l}\text { tidak terjadı } \\
\text { tetesan }\end{array}$ \\
\hline & D3 & 4.9 & & 0.00 & & 0.00 & & 0.00 & & $\begin{array}{l}\text { tidak terjadi } \\
\text { tetesan }\end{array}$ \\
\hline \multirow{3}{*}{$E$} & E1 & 4.9 & \multirow{3}{*}{4.92} & 0.00 & \multirow{3}{*}{0.00} & 0.00 & & 0.00 & \multirow{3}{*}{0.00} & terjadi tetesan \\
\hline & E2 & 4.9 & & 0.00 & & 0.00 & 0.00 & 0.00 & & terjadi tetesan \\
\hline & E3 & 4.95 & & 0.00 & & 0.00 & & 0.00 & & terjadi tetesan \\
\hline
\end{tabular}

\section{Bentuk/pandangan luar}

\section{Tepi potong, permukaan lembaran dan bidang potong}

Tepi potong, permukaan lembaran dan bidang potong lembaran dari hasil pengamatan secara visual terhadap tepi potong permukaan lembaran dan bidang potong Tabel 1 menunjukkan bahwa pada umumnya produk memenuhi syarat mutu lembaran serat semen yakni tepi potongnya lurus, rata dan tidak mengkerut, permukaan lembaran tidak memberikan retak-retak, kecuali untuk perlakuan $\mathrm{E} 1=\mathrm{E} 2=\mathrm{E} 3 \quad(\mathrm{E})$ dengan menggunakan gypsum1600 g, abu sekam padi $1000 \mathrm{~g}$, semen $1000 \mathrm{~g}$ dan serat sabut kelapa $215 \mathrm{~g}$ menghasilkan permukaan yang agak berlubang atau cacat lain.

\section{Kemampuan digergaji}

Hasil analisis kemampuan digergaji dari produk plafon serbuk kasar sabut kelapa dapat dilihat pada Tabel 1.Hasil penggergajian menunjukkan bahwa kemampuan digergaji dari produk adalah baik.Hal ini disebabkan karena penggunaan gypsum dan bahan tambahan laninya pada pembuatan plafon cukup seimbang sehingga produk yang diperoleh tidak terlalu keras [6].

\section{Kemampuan dipaku}

Hasil analisis produk plafon (Tabel 1) menunjukkan bahwa semua produk yang diperoleh dapat dipaku dengan baik. Hal ini 
disebabkan oleh jumlah abu sekam padi, serat sabut kelapa, gypsum dan semen yang seimbang menyebabkan campuran adonan lebih homogen dan lebih menyatuh serta kompak dan juga dipengaruhi oleh kehalusan partikel-partikel dari abu sekam padi dan bahan-bahan lainnya.

\section{E. Ukuran dan Sifat-sifat fisik}

1. Tebal

Hasil pengukuran terhadap tebal dari produk yang dihasilkan dapat dilihat pada Tabel 2 . Dari hasil yang diperoleh menunjukkan bahwa tebal produk berkisar 4,88-4,93 $\mathrm{mm}$. Tinggi dan rendahnya ketebalan yang diperoleh disebabkan oleh ukuran kehalusan dari abu sekam padi, yang mana kepadatan dari partikel-partikel semakin kurang menyatuh dengan bahan lainnya sehingga pada waktu ditekan kurang padat, demikian sebaliknya semakin halus semakin homogen sehingga pada waktu ditekan bahan lebih menyatuh sehingga memudahkan bahan lebih padat pada waktu ditekan dengan menggunakan tekanan $500 \mathrm{~kg} / \mathrm{cm}^{2}$ [7].

\section{Penyimpangan ukuran}

Dari hasil analisis pengukuran terhadap panjang dan lebar serta tebal dari produk yang dihasilkan menunjukkan bahwa adanya variasi jumlah serat sabut kelapa terjadi penyimpangan ukuran untuk beberapa perlakuan seperti terlihat pada Tabel 2.Dengan adanya variasi ini menyebabkan terjadinya penyimpangan ukuran. Penyimpangan ukuran panjang diperoleh pada perlakuan $\mathrm{A} 1=\mathrm{A} 2=\mathrm{A} 3(\mathrm{~A})$ yang menggunakan gypsum $1600 \mathrm{~g}$, semen
$1000 \mathrm{~g}$, abu sekam padi $1000 \mathrm{~g}$ dan serat sabut kelapa $135 \mathrm{~g}$ yaitu sebesar $0,48 \%$, lebar diperleh pada perlakuan $\mathrm{A} 1=\mathrm{A} 2=\mathrm{A} 3$ (A) yang menggunakan gypsum $1600 \mathrm{~g}$, semen $1000 \mathrm{~g}$, abu sekam padi $1000 \mathrm{~g}$ dan serat sabut kelapa $135 \mathrm{~g}$ sebesar 0,46\% dan penyimpangan tebal diperoleh pada perlakuan $\quad \mathrm{A} 1=\mathrm{A} 2=\mathrm{A} 3 \quad(\mathrm{~A})$ yang menggunakan gypsum $1600 \mathrm{~g}$, semen $1000 \mathrm{~g}$, abu sekam padi $1000 \mathrm{~g}$ dan serat sabut kelapa $135 \mathrm{~g}$ yaitu sebesar $8,12 \%$. Dari hasil penelitian yang diperoleh menunjukkan bahwa umumnya produk dapat memenuhi syarat mutu lembaran serat semen SNI 15-0233-1989. Terjadinya penyimpangan ini disebabkan oleh penggunaan jumlah air pada waktu pembuatan atau pencampuran adonan berbeda, dengan demikian air yang keluar pada waktu pencetakan/pengepresan berbeda sehingga menyebabkan pengeluaran air yang berbeda pula [8].

\section{Bobot Isi}

Hasil analisis produk plafon dari serbuk kasar sabut kelapa (Gambar 2) menunjukkan bahwa hasil bobot isi yang tertinggi diperoleh pada perlakuan $\mathrm{E} 1=\mathrm{E} 2=\mathrm{E} 3(\mathrm{E})$ yang menggunakan gypsum $1600 \mathrm{~g}$, semen $1000 \mathrm{~g}$, abu sekam padi $1000 \mathrm{~g}$ dan serat sabut kelapa $215 \mathrm{~g}$ yaitu sebesar $1.82 \mathrm{~g} / \mathrm{cm}^{3}$, sedangkan yang terendah diperoleh pada perlakuan $A 1=A 2=A 3(A)$ yang menggunakan gypsum $1600 \mathrm{~g}$, semen $1000 \mathrm{~g}$, abu sekam padi $1000 \mathrm{~g}$ dan serat sabut kelapa135 g yaitu sebesar $1.48 \mathrm{~g} / \mathrm{cm}^{3}$. 


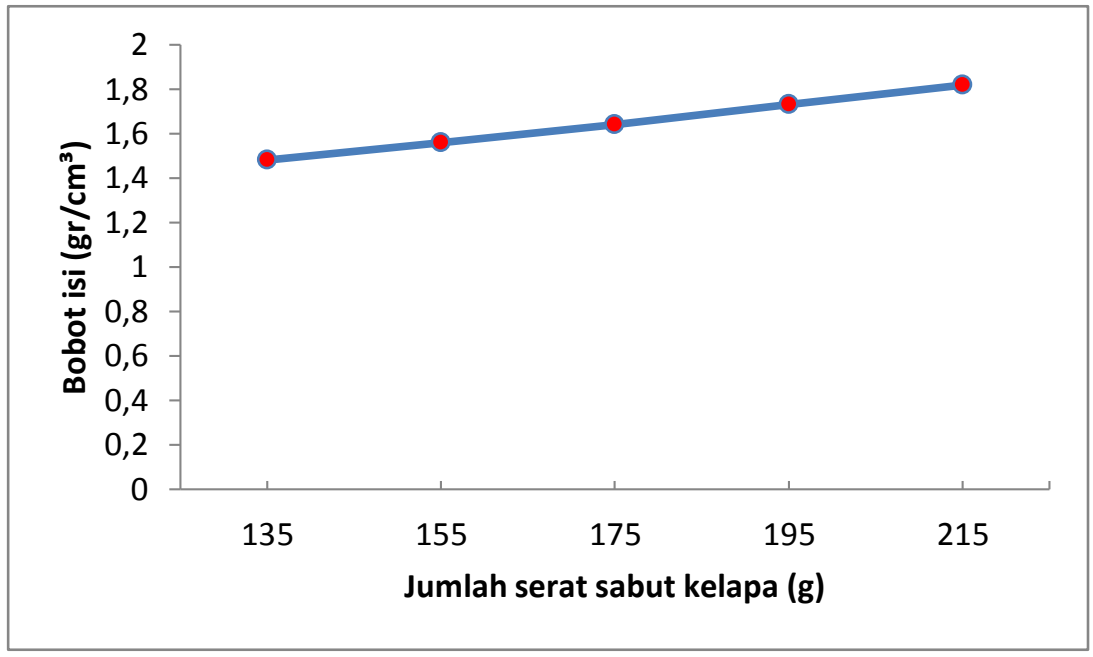

Gambar 2.Pengaruh jumlah serat sabut terhadap bobot isi dari produk plafon.

Tinggi dan rendahnya hasil bobot isi yang diperoleh disebabkan karena pengaruh dari abu sekam padi dan variasi jumlah serat sabut kelapa yang digunakan tidak terlalu besar jumlahnya, sehingga tidak menyebabkan peningkatan bobot isi terhadap produk plafon yang dihasilkan dan juga pada proses pencetakan adonan yang tidak sama rata sehingga tidak sesuai dengan ukuran tebal cetakan [9] .

\section{Penyerapan Air}

Hasil analisis produk plafon dari abu sekam padi dan serat sabut kelapa (Gambar 3) menunjukkan bahwa semua produk yang diperoleh memenuhi syarat mutu lembaran serat semen SNI 15-0233-1989.

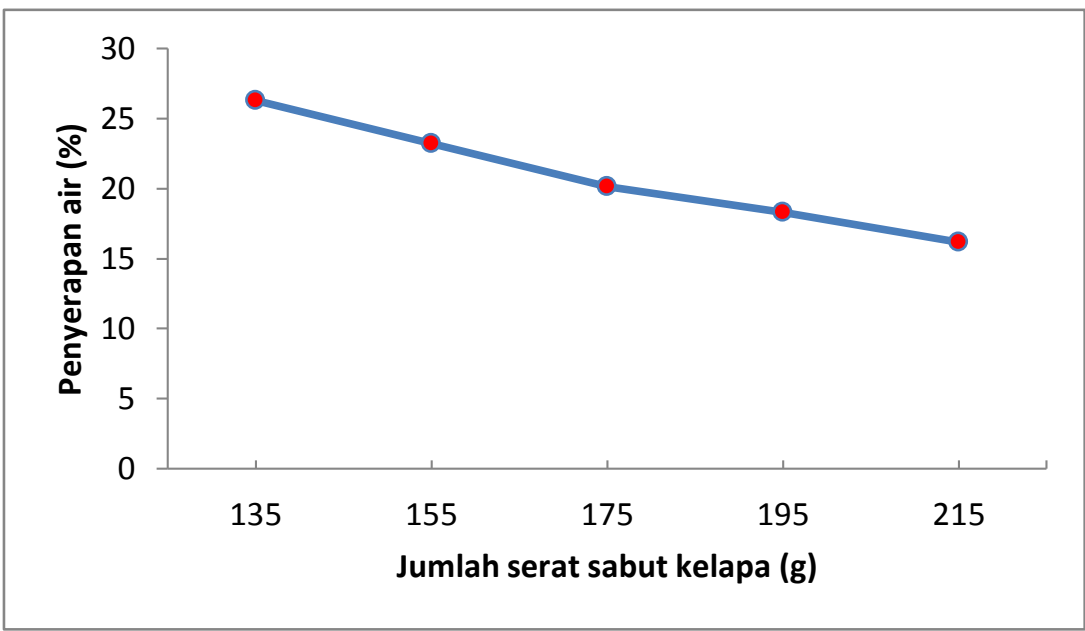

Gambar 3. Pengaruh jumlah serat sabut kelapa terhadap penyerapan air dari produk plafon

Hasil yang tertinggi dperoleh pada perlakuan $\mathrm{A} 1=\mathrm{A} 2=\mathrm{A} 3$

(A) dengan menggunakan gypsum $1600 \mathrm{~g}$, semen $1000 \mathrm{~g}$, abu sekam padi $1000 \mathrm{~g}$ dan serat sabut kelapa $135 \mathrm{~g}$ yaitu sebesar $26,28 \%$ dan yang terendah diperoleh pada perlakuan $\quad \mathrm{E} 1=\mathrm{E} 2=\mathrm{E} 3 \quad(\mathrm{E})$ yang menggunakan gypsum 1600 g, semen
$1000 \mathrm{~g}$, abu sekam padi $1000 \mathrm{~g}$ dan serat sabut kelapa $215 \mathrm{~g}$ yaitu sebesar 16,15\%. Hasil yang diperoleh cenderung menurun disebabkan karena penggunaan jumlah serat sabut kelapa yang digunakan yaitu semakin tinggi jumlahnya dan juga penggunaan gypsum dan abu sekam padi dan sifat atau karakteristik yang dapat 
menyerap air yang tinggi sehingga hasil yang diperoleh semakin turun [10] .

\section{Kerapatan Air}

Hasil analisis produk plafon dari serbuk sabut kelapa (Tabel 2) menunjukkan bahwa perlakuan produk yang diperoleh pada umunya memenuhi sayarat mutu lembaran serat semen, kecuali perlakuan $\mathrm{E} 1=\mathrm{E} 2=\mathrm{E} 3(\mathrm{E})$ dengan menggunakan serat sabut kelapa $215 \mathrm{~g}$ menghasilkan produk yang tidak baik karena dapat terjadi tetesan air. Hal ini disebab karena produk yang diperoleh permukaan lembaran agak berlubang sehingga terjadi tetesan atau perembesan akan lebih tinggi dan sebaliknya produk plafon yang tidak terjadi tetesan atau tidak merembes disebabkan serat sabut kelapa yang digunakan cukup seimbang dengan bahan pengisi serat sabut kelapa dan juga dipengaruhi oleh abu sekam padi, semen dan gypsum yang digunakan sehingga pembuatan produk lebih homogen dan lebih menyatuh atau lebih padat [11].

\section{Kuat lentur}

Hasil analisis produk plafon dari abu sekam padi dan sabut kelapa (Gambar 4) menunjukkan bahwa variasi jumlah serat sabut kelapa memberikan hasil yang nyata terhadap kuat lentur dari produk plafon yang dihasilkan. Hasil yang tertinggi diperoleh pada perlakuan $\mathrm{C} 1=\mathrm{C} 2=\mathrm{C} 3(\mathrm{C})$ dengan menggunakan gypsum $1600 \mathrm{~g}$, semen $1000 \mathrm{~g}$, abu sekam padi $1000 \mathrm{~g}$ dan serat sabut kelapa $175 \mathrm{~g}$ yaitu sebesar $105.80 \mathrm{~kg} / \mathrm{cm}^{2}$ dan yang terendah diperoleh pada perlakuan $\mathrm{A} 1=\mathrm{A} 2=\mathrm{A} 3$ (A) dengan menggunakan gypsum $1600 \mathrm{~g}$, semen $1000 \mathrm{~g}$, abu sekam padi $1000 \mathrm{~g}$ dan serat sabut kelapa $135 \mathrm{~g}$ yaitu sebesar 61,06 $\mathrm{kg} / \mathrm{cm}^{2}$.

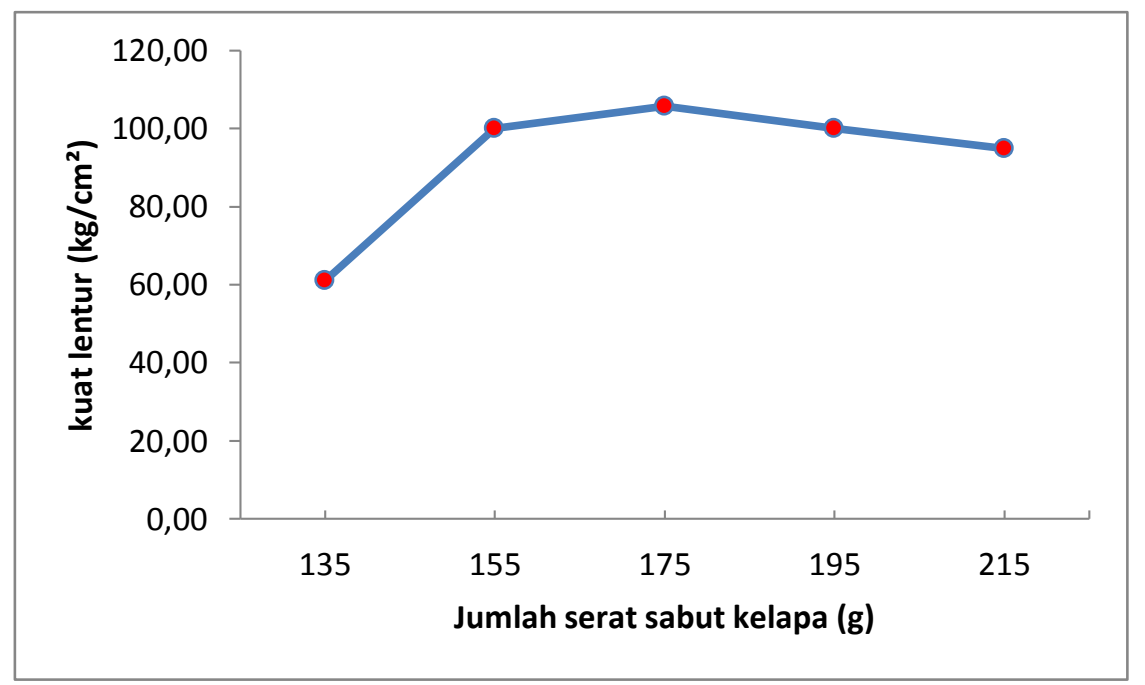

Gambar 4.Pengaruh jumlah serat sabut kelapa terhadap kuat lentur dari produk plafon.

Tinggi dan rendahnya kuat lentur dari produk yang diperoleh hal ini disebabkan semakin besar jumlah serat sabut kelapa yang digunakan menyebabkan adonan atau campuran gypsum, semen dan abu sekam padi lebih seimbang sehingga dapat menyatuh lebih sempurna, dan pada waktuproses pembuatan serta pencetakan plafon yang diperoleh lebih padat atau lebih kompak dan lebih tangguh sehingga 
menyebabkan kekuatan lebih tinggi [12]. Dari hasil yang diperoleh ternyata bahwa perlakuan yang memenuhi syarat mutu slembaran serat semen SNI 15-0233-1989 dengan perlakuan $\mathrm{B} 1=\mathrm{B} 2=\mathrm{B} 3 \quad(\mathrm{~B})$ yang menggunakan serat gypsum $1600 \mathrm{~g}$, semen $1000 \mathrm{~g}$, abu sekam padi $1000 \mathrm{~g}$ dan sabut kelapa $155 \mathrm{~g}$ yaitu sebesar 100,15 $\mathrm{kg} / \mathrm{cm}^{2}$, perlakuan $\mathrm{C} 1=\mathrm{C} 2=\mathrm{C} 3$ (C) yang menggunakan gypsum $1600 \mathrm{~g}$, semen $1000 \mathrm{~g}$, abu sekam padi $1000 \mathrm{~g}$ dan serat sabut $175 \mathrm{~g}$ yaitu sebesar $105,8 \mathrm{~kg} / \mathrm{cm}^{2}$ dan perlakuan $\quad \mathrm{D} 1=\mathrm{D} 2=\mathrm{D} 3 \quad$ (D) yang menggunakan gypsum $1600 \mathrm{~g}$, semen 1000 g, abu sekam padi $1000 \mathrm{~g}$ dan serat sabut kelapa $195 \mathrm{~g}$ yaitu sebesar $102,15 \mathrm{~kg} / \mathrm{Cm}^{2}$

\section{KESIMPULAN}

Hasil penelitian pembuatan plafon dengam menggunakan bahan-bahan yang konstan: gypsum, semen, abu sekam padi, sedangkan serat sabut kelapa sebagai variabel ternyata bahwa dapat menghasilkan plafon untuk bahan bangunan, kecuali perlakuan $E$ yang menggunakan serat sabut kelapa $215 \mathrm{~g}$, $1600 \mathrm{~g}$ gypsum, semen $1000 \mathrm{~g}$ dan abu sekam padi 1000 g.Hasil penelitian menunjukkan bahwa hasil bobot isi yaitu $1,48-1,82 \mathrm{~g} / \mathrm{cm}^{3}$, penyerapan air 16,15 $26,28 \%$ dan kuat lentur 61,06-105.80 $\mathrm{kg} / \mathrm{cm}^{2}$,kemampuan digergaji dan dipaku dalam keadaan baik, bidang potong yaitu campuran yang merata, tidak berlubang tidak terbelah-belah, tepi potong yaitu lurus , rata, tidak mengerut, sama tebalnya, permukaan lembaran tidak retak-retak,tidak berlubang atau cacat lain, kecuali perlakuan A terjadi penyimpangan: panjang $0,00-0,48 \%$, tebal $0,00-8.12 \%$ dan lebar 0,00-0,46\%. Dan perlakuan E yang permukaan lembaran tidak retak-retak, tetapi agak berlubang atau cacat lain dan terjadi tetesan air. Hasil penelitian ternyata bahwa perlakuan yang terbaik diperoleh pada perlakuan B,C dan D dengan menggunakan gypsum $1600 \mathrm{~g}$, abu sekam padi $1000 \mathrm{~g}$, semen $1000 \mathrm{~g}$ dan serat sabut kelap 155-195 g, menghasilkan kuat lentur 100.15-105.80 kg/cm ${ }^{2}$ dapat dipaku, digergaji, tidak terjadi tetesan air.

\section{DAFTAR PUSTAKA}

1. Kumar $P$ M, Paulo J M, Monteiro. Concrete Micro Structur Properties and Materials. Mc Graw-HiLL. USA. Third edition. 2007.

2. Sulawesi Utara dalam Angka Tahun 2015. Dinas Perkebunan Provinsi Sulawesi Utara.

3. SNI No.15-0233-1989 Syarat Mutu Lembaran Serat. Badan Standardisasi Nasional. 1989.

4. Swastika N. Kajian Terhadap Bentop Poimer Dengan Bahan Tambahan Abu Sekam Padi. Jurnal Teknik Sipil Institut Teknologi Bandung. 2010.

5. Oro J, Frans P, Sappu, Romels Lumintang. Analisis Sifat Mekanik Material Komposit dari Serat Sabut Kelapa, Universitas Sam Ratulangi Manado. 2013.

6. Nawy, Edward G. Concenrate Construction Enginering Handbook. Talor \& Francis Group. Second Edition. USA. 2010.

7. Simatupang. Pemanfaatan Gypsum Sebagaia Bahan Bangunan. Universitas Sumatra Utara. Medan. 1985.

8. Anomim. Pabrik Silika, tersedia di http/digilib.it.Ac.id/publish/ITS. Diakses pada tanggal 5 Oktober 2010.

9. Zerbino $R$, etc. Alkali Silica Reaction in Mortar in Coorporation Natural Rice Husk Ash. Contruction and Building Material. 86 145-151. 2012.

10. Elhusna. Pengaruh Serat Sabut Kelapa terhadap Kuat Lentur Beton dengan Faktor Air Semen. Jurnal Volume 3 Program Studi Teknik Sipil Universitas Bengkulu. Bengkulu. 2011.

11. Nurmaulita. Pengaruh Orientasi Serat Sabut Kelapa dengan Resin Poliester 
Karakteristik Papan lembaran Universitas Sumatra Utara. 2010.

12. Suluch M. Penelitian Pengembangan Prototip Rumah Cepat Type Rumah Sederhana Sehat. Laporan Penelitian Kerja Sama LPPM-Its dengan BalaiTeknologi Pemukiman Provinsi Jawa Timur. 2007. 
